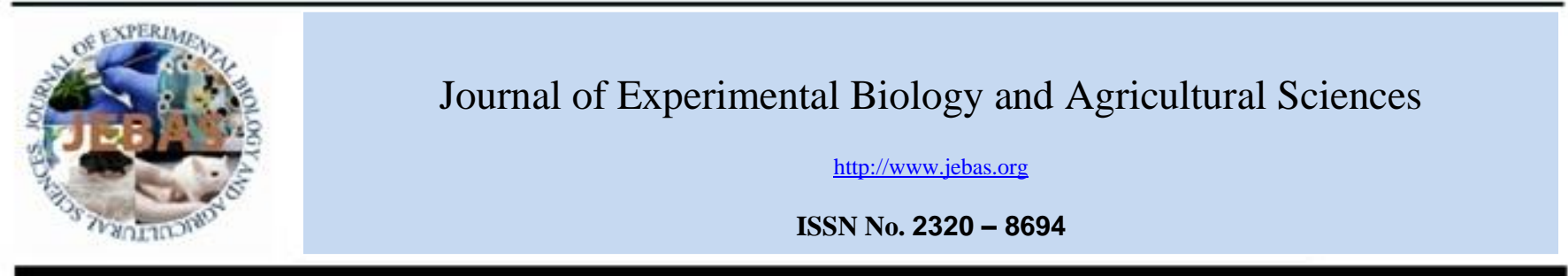

\title{
ANTI-BACTERIAL ACTIVITY OF Trigonella foenum-graecum AGAINST SKIN PATHOGENS
}

\section{Geetha Subramaniam*, Rayshen Renganaden Poolee Cootee, Cheah Cheng Han, Lalita Ambigai Sivasamugham}

INTI International University, Persiaran Perdana BBN, Putra Nilai, 71800 Nilai, Negeri Sembilan, Malaysia

Received - July 18, 2020; Revision - September 17, 2020; Accepted - December 08, 2020

Available Online - March 25, 2021

DOI: http://dx.doi.org/10.18006/2021.9(Spl-1-GCSGD_2020).S110.S115

Keywords

Trigonella foenum graecum

MRSA

MRSE

Anti-bacterial

\begin{abstract}
The increase in antibiotic resistance globally necessitates the search for alternative therapeutic agents. Among the common antibiotic-resistant bacteria, MRSA and MRSE cause a wide range of infections with limited treatment options. Trigonella foenum-graecum has been widely used particularly in Asian countries in food and as a supplement. In this study, the anti-bacterial activity of T. foenum-graecum essential oil, boiled aqueous and ethanolic extracts was determined against Staphylococcus aureus, Staphylococcus epidermidis, Propionibacterium acnes, MRSA, and MRSE by using the agar well diffusion assay. For determination of the zone of inhibition, Clindamycin $(2 \mu \mathrm{g} / \mathrm{disc})$ was used as a comparison for the anti-bacterial susceptibility results. The maximum zone of inhibition was observed with the boiled aqueous extracts of $T$. foenum-graecum against MRSA $(20 \mathrm{~mm})$, while the essential oil and ethanolic extracts of $T$. foenum-graecum did not show any zones of inhibition against all the tested staphylococcal and P. acnes isolates. Qualitative phytochemical analysis revealed the presence of flavonoids and terpenoids in all three extracts tested, among these boiled aqueous extract contained the highest number of phytochemicals which could account for the higher anti-bacterial activity exhibited by the boiled aqueous extracts. Hence, the $T$. foenum-graecum seeds show a potential application as an anti-bacterial agent against skin pathogens, particularly in the formulation of a skincare product.
\end{abstract}

* Corresponding author

E-mail: geetha.subramaniam@newinti.edu.my (Geetha Subramaniam)

Peer review under responsibility of Journal of Experimental Biology and Agricultural Sciences.

Production and Hosting by Horizon Publisher India [HPI] (http://www.horizonpublisherindia.in/).

All rights reserved.
All the articles published by Journal of Experimental Biology and Agricultural Sciencesare licensed under a Creative Commons Attribution-NonCommercial 4.0 International License Based on a work at www.jebas.org.

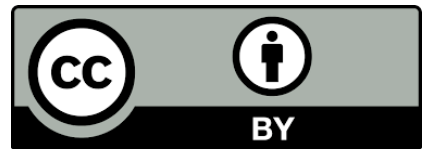




\section{Introduction}

Plant extracts have been used throughout generations to remediate human diseases (Brown \& Wright, 2016). It is believed that up to $70 \%$ to $90 \%$ of the populations in developing countries use plant extracts as remedies (Chin et al., 2006). Indiscriminate uses of antibiotics has led to the emergence of antibiotic-resistance in pathogenic bacterial strains and this increases the demand for alternative anti-bacterial substances obtained from natural sources, mainly from medicinal plants (Khan et al., 2017).

Infections caused by Methicillin-resistant Staphylococcus aureus (MRSA) and Methicillin-resistant Staphylococcus epidermidis (MRSE) are a major health problem, globally (Livermore, 2000). According to the CDC (Centers for Disease Control and Prevention, 2019), MRSA is responsible for skin, wounds, bloodstream infections, and pneumonia. In the US (United States) 120,000 cases of severe MRSA infections followed by 20,000 deaths per annum were recorded in 2017 , and it was found that these isolates also had resistance against various commonly used antibiotics such as nafcillin, oxacillin, and cephalosporins (CDC 2019). MRSE, on the other hand, is becoming increasingly prevalent as a cause of bacteremia (Kleinschmidt et al., 2015). Furthermore, the prevalence of multidrug resistance in MRSA isolates, in particular, is resulting in an increase in mortality rates as well as healthcare costs (Lakhundi \& Zhang, 2018). As there are decreasing antibiotic treatment options for MRSA and MRSE infections, there is an urgent need for alternative remedies to help curb the spread of this alarming threat.

Trigonella foenum-graecum (commonly known as fenugreek), is a member of the family Leguminosae. The seeds and leaves of $T$. foenum-graecum, are frequently used as spices to enhance food flavor and are a rich source of nutrients and natural fiber (Srinivasan, 2006). The anti-oxidative and anti-diabetic properties exhibited by $T$. foenum-graecum have resulted in the common use of this herb in Ayurvedic medicine (Dixit et al., 2005; Kannappan \& Anuradha, 2009). Antimicrobial screening using fenugreek seed extracts has shown positive inhibitory effects against $S$. aureus, $S$. epidermidis, Escherichia coli, and Proteus vulgaris which shows potential antimicrobial effects against these pathogens (Walli et al. 2015).

The chemical constituents in $T$. foenum-graecum that contribute to the therapeutic benefits of this plant include flavonoids, saponins, and other rare constituents such as coumarin, trigonelline, fenugreekine, and many more (Michael \& Kumawat, 2003; Snehlata \& Payal, 2012). These phytochemicals have been linked to antibacterial activity against various bacterial species (Gill \& Holley, 2006; Tiwari et al., 2009). Another factor that could influence the intensity of the antimicrobial activity of plant extracts, in general, could be the solvent used to extract the phytochemical constituents (Dhanani et al., 2017; Fehli et al., 2017).

This research was carried out to analyze the phytochemical content of the essential oils, ethanolic extracts, and aqueous extracts of $T$. foenum-graecum and the potency of its anti-bacterial effect against MRSA and MRSE and other skin pathogens.

\section{Materials and Methods}

\subsection{Bacterial isolates}

Bacterial isolates that were used included MRSA, MRSE, $S$. aureus, S. epidermidis, and Propionibacterium acnes. All these isolates were provided by INTI International University, Malaysia, and were cultured on nutrient agar before further testing.

\subsection{Confirmatory tests}

Basic biochemical tests were performed on each bacterial isolate to confirm their identity. The Gram stain was done using an overnight bacterial culture smear as previously described (Beveridge \& Davies, 1983). The presence of catalase in each bacteria was determined using $3 \%(\mathrm{v} / \mathrm{v}) \mathrm{H}_{2} \mathrm{O}_{2}$ mixed into a single colony of the individual cultures and observing for the formation of bubbles (Taylor \& Archanzar, 1972). All isolates were streaked onto mannitol salt agar (MSA) and incubated at $37^{\circ} \mathrm{C}$ overnight to observed bacterial growth and change in the color of media. MRSA and MRSE isolates were confirmed as being resistant using the cefoxitin disk diffusion assay (Bonjean et al., 2016). All bacterial culture work was carried out under aseptic conditions in a lamina air-flow cabinet.

\subsection{T. foenum-graecum seed extract preparation}

T. foenum-graecum seeds were obtained from two different states of Malaysia viz., Penang (S1) and Negeri Sembilan (S2) for a more unbiased testing to determine if the results obtained were similar despite the origin of the plant material. The seeds were rinsed briefly with distilled water and $70 \%$ (V/V) ethanol before drying under the sun for 1 day. From the collected seeds, 50\% of the healthy seeds were ground into a fine powder and extracted with $80 \%$ ethanol using a Soxhlet extractor, and concentrated using a rotary evaporator (Chua et al., 2019). The remaining seeds were boiled with distilled water in a ratio of $1: 2$ for 15 minutes, filtered, and cooled at room temperature. The pure essential oil of $T$. foenum-graecum (Naturelife and BioFinest) was purchased online.

\subsection{Determination of anti-bacterial activity}

A fresh bacterial suspension was prepared in sterile distilled water and compared against the $0.5 \mathrm{McF}$ arland standard to obtain a concentration of approximately $5 \mathrm{X} 105 \mathrm{CFU} / \mathrm{mL}$. The suspension 
$(50 \mu \mathrm{L})$, was lawned onto Mueller-Hinton agar (MHA) plates and left to dry for 15 minutes in a biohazard cabinet (CLSI, 2018). A well was bored into the middle of the quadrant of the agar plates. A total volume of $400 \mu \mathrm{L}$ of plant extract was applied into the appropriate well of the plate. Concentrated essential oil $(50 \mu \mathrm{L})$ was applied to sterile disks and placed on the labeled quadrant Clindamycin $(2 \mu \mathrm{g} / \mathrm{disk})$, was used as a comparison of antibacterial activity. The zone of inhibition diameter was measured after a 24-hour incubation at $37 \circ \mathrm{C}$. The diffusion assays were performed in triplicates.

\subsection{Phytochemical screening}

Qualitative analysis of phytochemical compounds present in $T$ foenum-graecum was performed on the essential oil, ethanolic extracts, and boiled aqueous extracts. The phytochemicals screened for included secondary metabolites such as flavonoids, saponins, terpenoids, alkaloids, phenols, and tannins, using different methods as previously described (Kumari et al., 2016).

\subsection{Statistical analysis}

Statistical comparisons were performed using ANOVA Post Hoc Tests in IBM SPSS for one-way ANOVA. P-value is lesser than 0.05 were used to confirm significant differences between the means of different sets of data as this experiment was repeated in triplicates to obtain more reliable results.

\section{Results and Discussion}

Essential oil and two different solvent extracts of $T$. foenumgraecum seeds (obtained from two different locations of Malaysia) were used to determine the antibacterial effects of these preparations against common skin pathogens. Two sources of seeds were used to ensure the antibacterial activity was due to the active ingredients of $T$. foenum-graecum seeds and not affected by the particular source from which it was obtained. In this study, both seed sources yielded similar results in the assays conducted, therefore the combined mean zones of inhibition were analyzed.

Previous studies have shown that essential oils generally have significantly higher activity against bacterial isolates, particularly against Gram-positive bacteria, which could be because essential oils are generally in concentrated form and contain a higher quantity of terpenoids (Subramaniam et al., 2020).

Hence, the essential oils are usually used in smaller quantities of testing in disk diffusion assays. The concentration of the ethanolic extract of T. foenum-graecum was almost half of that of the boiled aqueous extract (Table 1).

Significant differences in anti-bacterial activity were observed among the three different extracts of $T$. foenum-graecum $(\mathrm{p}<0.05)$, with the boiled aqueous extract exhibiting the highest activity at a concentration of $500 \mathrm{mg} / \mathrm{ml}$ (Table 1).

Overall, the anti-bacterial activity of boiled aqueous extracts of $T$. foenum-graecum was more effective against the staphylococci isolates but not against the $P$. acnes isolate. While the ethanolic extracts are more effective than aqueous extracts as has been previously reported for the other plant's ethanolic extracts (Fehli et al., 2017). However, despite the lower concentration of the ethanolic extract in this study, a zone of inhibition would have been expected to form, whereas none was observed.

The antibacterial activity of $T$. foenum-graecum was evaluated against clindamycin $(02 . \mathrm{ug} / \mathrm{ml})$ to assess the significance of this herb against the currently used antibiotic in the treatment of staphylococcal infections (Figure 1). Although, clindamycin was generally more effective against the tested bacterial isolates it should be noted that zones of inhibition more than or equal to 15 $\mathrm{mm}$ are considered significant and the isolate tested is said to be susceptible to the agent tested (BSAC, 2015).The MRSA isolate was susceptible to the boiled aqueous extract of $T$. foenumgraecum but resistant to clindamycin which is a promising result of the anti-bacterial effects of this seed extract against resistant pathogens.

Phytochemical screening of the three extracts of $T$. foenumgraecum showed a higher number of phytochemicals present in the boiled aqueous extract compared to the essential oil and the ethanolic extract (Table 2). This could be the reason for the more significant anti-bacterial effects of the boiled aqueous extract on the bacteria tested compared to the other two extracts.

The absence of alkaloids could have an impact on the overall antibacterial activity of the essential oil and ethanolic extracts. Similar findings were observed by Chua et al. (2019), whereby the ethanolic extracts of $T$. foenum-graecum did not yield any zones of inhibition when tested against $S$. aureus.

Aqueous extracts have generally been known to have less activity against bacteria tested (Ngo et al., 2017; Subramaniam et al., 2020). This could be due to the lower content of secondary metabolites extracted as found by Ngo et al. (2017). However, in this study, it was reported that boiled extracts of $T$. foenum-graecum, had significant antibacterial activity against the staphylococci isolates tested. This is concurrent with the findings of Walli et al. (2015) who showed that boiled aqueous extracts of $T$. foenum-graecum had significant antibacterial activity against both Gram-positive and Gram-negative bacteria, compared to hot and cold aqueous extracts which yielded little or no activity. Hence the boiling of the seeds of this plant could have contributed to the increase in secondary metabolites present in this preparation. A study by Truong et al. (2019) also showed comparably high phytochemical extraction yield compared to ethanol, in their study with Severinia buxifolia. 
Table 1 Anti-bacterial activity of fenugreek essential oil and seed extracts against skin pathogens

\begin{tabular}{|cccccc|}
\hline \multirow{2}{*}{ Extracts } & $\begin{array}{c}\text { Concentration of } \\
\text { extracts }\end{array}$ & S. aureus & S. epidermidis & P. acnes & MRSA \\
\hline Essential oil & N.A. & 0 & 0 & 0 & 0 \\
\hline Ethanolic & $330 \mathrm{mg} / \mathrm{ml}$ & 0 & 0 & 0 & 0 \\
\hline Boiled aqueous & $500 \mathrm{mg} / \mathrm{ml}$ & 16.83 & 17.0 & 12.0 & 20.16 \\
\hline
\end{tabular}

Table 2 Phytochemical screening of fenugreek essential oil and seeds crude extracts

\begin{tabular}{|cccc|}
\hline & & Extracts & Aqueous \\
\hline Phytochemicals & Essential oil & Ethanolic & $\mathrm{P}$ \\
\hline Flavonoids & $\mathrm{P}$ & $\mathrm{P}$ & $\mathrm{P}$ \\
\hline Saponins & $\mathrm{P}$ & $\mathrm{N}$ & $\mathrm{P}$ \\
\hline Terpenoids & $\mathrm{P}$ & $\mathrm{P}$ & $\mathrm{P}$ \\
\hline Alkaloids & $\mathrm{N}$ & $\mathrm{N}$ & $\mathrm{P}$ \\
\hline Phenols \& Tannins & $\mathrm{N}$ & $\mathrm{N}$ & \\
\hline
\end{tabular}

P indicates presence while $\mathrm{N}$ indicates the absence of phytochemicals in the plant extracts

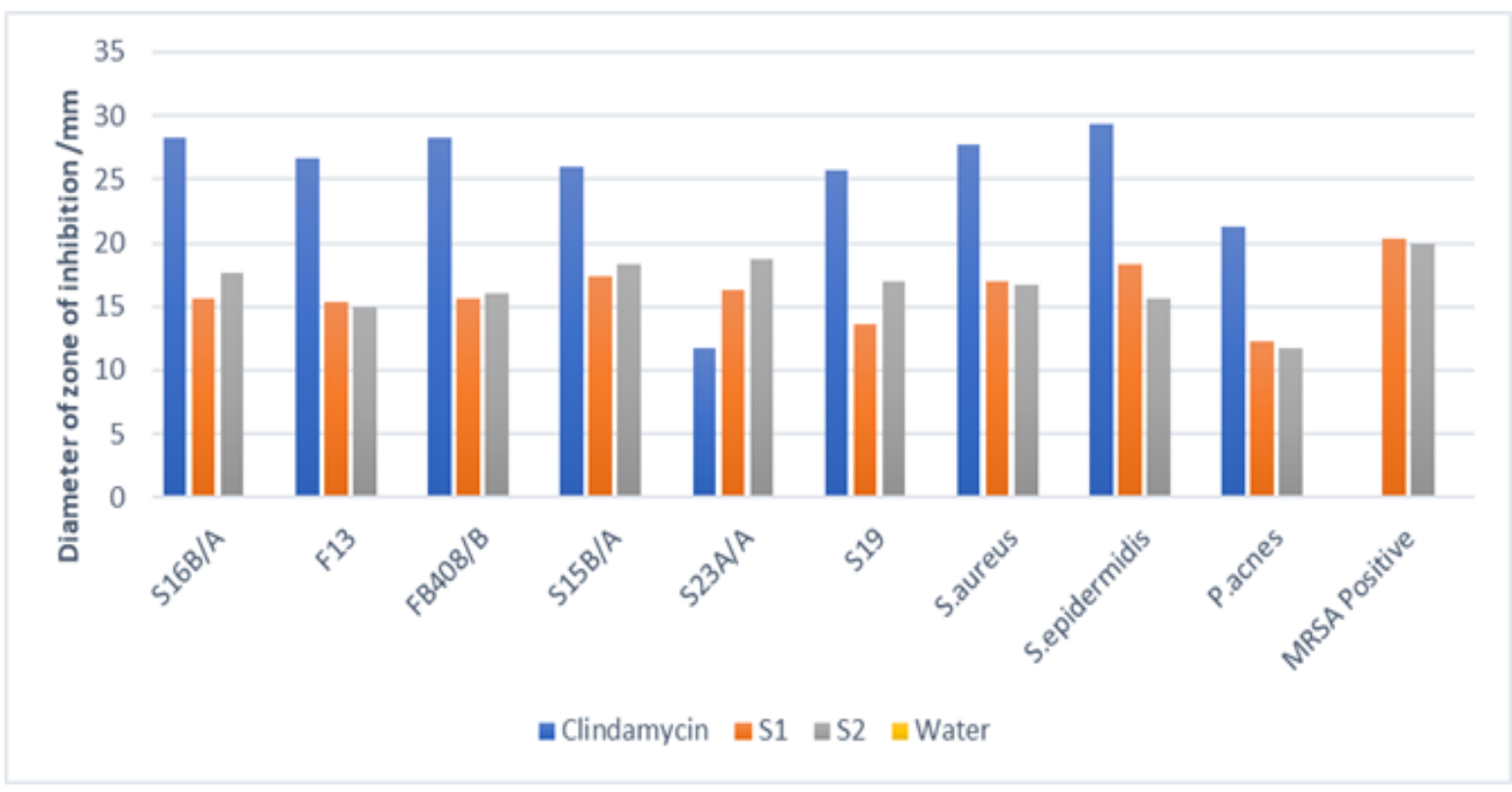

Figure 1 Mean zones of inhibition of T. foenum graecum boiled aqueous extracts $(500 \mathrm{mg} / \mathrm{ml})$ against staphylococcal and $P$. acnes isolates *Note: Staphylococcal isolates used in this study were MRSA (S16B/A, F13, FB408/B) and MRSE (S15B/A, S23A/A, S19), S. aureus and S. epidermidis

Journal of Experimental Biology and Agricultural Sciences http://www.jebas.org 
HPLC analysis of the secondary metabolites contained in various solvents revealed that the best concentration of ethanol for the extraction of these bioactive compounds was $50 \%$ and much lower for $100 \%$ ethanol (ElNour et al., 2015; Ngo et al., 2017). This could explain why the ethanolic extracts in this study (85\%) did not yield any zones of inhibition when tested against the bacterial isolates.

A study by Hozzein et al. (2020) showed that treatment of plant material with $\mathrm{CO}_{2}$ induced accumulation of secondary metabolites including phenolics, flavonoids, saponins, and alkaloids in the fenugreek seed extracts. This pre-treatment of the fenugreek seeds could be used to further enhance the quantity and phytochemical activity of the boiled extracts.

MRSA and MRSE are becoming more prevalent as communityacquired pathogens. Many individuals harbor these resistant pathogens in a carrier status. This poses a challenge as they could be spreading these multi-drug resistant bacteria unconsciously making the threat of antibiotic resistance even more difficult to overcome. The development of skincare products using plant sources is common in some Asian countries but to date, T. foenumgraecum has not been utilized in this manner. The fact that there is significant anti-bacterial activity exhibited by the boiled aqueous extracts of $T$. foenum-graecum against the staphylococci including the resistant members of this group, is promising.

\section{Conclusion}

This study shows the potential benefits of $T$. foenum-graecum as an anti-bacterial agent against common skin pathogens including MRSA and MRSE. Further studies should be conducted on more bacterial isolates from skin samples to conclusively prove the potential benefit of $T$. foenum-graecum is being utilized as a skincare product.

\section{Acknowledgments}

This study was supported by INTI International University Seeding Grant (INTI-FHLS-01-04-2018).

\section{Conflict of interest}

The authors declare that they have no conflict of interest.

\section{References}

Beveridge TJ, Davies JA (1983) Cellular responses of Bacillus subtilis and Escherichia coli to the Gram stain. Journal of Bacteriology 156: 846-858.

British Society for Antimicrobial Chemotherapy (BSAC) (2015) BSAC methods for antimicrobial susceptibility testing 14: 19 .
Brown ED, Wright GD (2016) Antibacterial drug discovery in the resistance era. Nature 529: 336-343.

Bonjean M, Hodille E, Dumitrescu O, Dupieux C, Mongo CN, Allam C, Beghin M, Paris M, Borrel O, Chardon H, Laurent F, Rasigade JP, Lina G (2016) Disk diffusion testing for detection of methicillin-resistant staphylococci: does moxalactam improve upon cefoxitin? Journal of Clinical Microbiology 54: 2905-2909.

CDC (2019) Antibiotic resistance threats in the United States Retrieved from: https://www.cdc.gov/drugresistance/pdf/threatsreport/2019-ar-threats-report-508.pdf, http://dx.doi.org/10.15620/cdc:82532.

2019. DOI:

Chin YW, Balunas MJ, Chai HB, Kinghorn AD (2006) Drug discovery from natural sources. American Association of Pharmaceutical Scientists Journal 8: E239-E253.

Chua YH, Perveen N, Paliwal N, Khan NH (2019) Phytochemical screening, antimicrobial and antioxidant activity determination of Trigonella foenum-graecum seeds. Pharmacy and Pharmacology International Journal 7: 175-186.

Clinical and Laboratory Standards Institute (CLSI) (2018) Performance standards for antimicrobial testing, approved guidelines, 28th ed., M100.

Dhanani T, Shah S, Gajbhiye NA, Kumar S (2017) Effect of extraction methods on yield, phytochemical constituents and antioxidant activities of Withania somnifera. Arabian Journal of Chemistry 10: S1193-1199.

Dixit PP, Ghaskadbi S, Mohan H, Devasagayam TP (2005) Antioxidant properties of germinated fenugreek seeds. Phytotherapy Research 19: 977-983.

EINour MEM, Ali AMA, Saeed BEAE (2015) Antimicrobial activities and phytochemical screening of callus and seed extracts of fenugreek (Trigonella foenum-graecum). International Journal of Current Microbiology and Applied Science 4: 147-157.

Felhi S, Daoud S, Hajlaoui S, Mnafgui K, Gharsalleh N Kadri A (2017) Solvent extraction effects on phytochemical constituent profiles, antioxidant and antimicrobial activities and functional group analysis of Ecballium elaterium seed and peel fruits. Food Science and Technology Campinas 37: 483-492.

Gill AO, Holley RA (2006) Disruption of Escherichia coli, Listeria monocytogenes and Lactobacillus sakei cellular membranes by plant oil aromatics. International Journalof Food Microbiology 108: $1-9$. 
Hozzein WN, Saleh AM, Habeeb TH, Wadaan MAM, Elgawad $\mathrm{HA}$ (2020) $\mathrm{CO}_{2}$ treatment improves the hypocholestronemic and anti-oxidant properties of fenugreek seeds. Food Chemistry 308 https://doi.org/10.1016/j.foodchem.2019.125661.

Kannappan S, Anuradha CV (2009) Insulin sensitizing effects of fenugreek seed polyphenols, quercetin and metformin in a rat model. Indian Journal of Medical Research 129: 401-408.

Khan S, Imran M, Pindari N (2017) Antimicrobial activity of various ethanolic plant extracts against pathogenic multi-drug resistant Candida species. Bioinformation 13: 66-72.

Kleinschmidt S, Huygens F, Faoagali J, Rathnayake IU, Hafner LM (2015) Staphylococcus epidermidis as a cause of bacteremia. Future Microbiology 10: 1859-1879.

Kumari O, Rao NB, Gajula RG (2016) Phytochemical analysis and anti-microbial activity of Trigonellafoenum-graecum (methi seeds). International Journal of Pharmacy 7: 83-86.

Lakhundi S, Zhang K (2018) Methicillin-resistant Staphylococcus aureus: molecular characterization, evolution and epidemiology. Clinical Microbiology Reviews 31: 1 - 103.

Livermore DM (2000) Antimicrobial resistance in Staphylococci. International Journal of Antimicrobial Agents 16: S3-S10.

Michael D, Kumawat D (2003) Legend and archeology of fenugreek, constituents and modern applications of fenugreek seeds International Sympozium USA 41-42.

Ngo TV, Scarlett CJ, Bowyer MC, Ngo PD, Vuong QV (2017) Impact of different extraction solvents on bioactive compounds and antioxidant capacity from the root of Salacia chinensis L.
Journal of Food Quality article i.d.9305047

DOI:10.1155/2017/9305047.

Snehlata HS, Payal DR (2012) Fenugreek (Trigonella foenumgraecum L.): an overview. International Journal of Current Pharmaceutical Review and Research 2: 169-187.

Srinivasan K (2006) Fenugreek (Trigonella foenum-graecum): a review of health beneficial physiological effects. Food Reviews International 22: 203-224.

Subramaniam G, Yew XY, Sivasamugham LA (2020) Antibacterial activity of Cymbopogan citratus against clinically important bacteria. South African Journal of Chemical Engineering 34: $26-30$.

Taylor WI, Archanzar D (1972) Catalase test as an aid to the identification of Enterobacteriaceae. Journal of Applied Microbiology 24: 58-61.

Tiwari BK, Valdramidi VP, O'Donnell CP, Muthukumarappan K, Bourke P, Cullen PJ (2009) Application of natural antimicrobials for food preservation. Journal of Agricultural and Food Chemistry 57: 5987-6000.

Truong DH, Nguyen DH, Ta NTA, Bui AV, Do TH, Nguyen HC (2019) Evaluation of the use of different solvents for phytochemical constituents, antioxidants and in vitro antiinflammatory activities of Severinia buxifolia. Journal of Food Quality article id 8178294, 9 pages, https://doi.org/10.1155/2019/8178294.

Walli RR, al-Musrati RA, Eshtewi HM, Sherif FM (2015) Screening of antimicrobial activity of fenugreek seeds. Pharmacy and Pharmacology International Journal 2 00028. DOI: 10.15406/ppij.2015.02.00028. 